\title{
Pengaruh Komposisi Azolla pinnata Pada Pakan Terhadap Pertumbuhan Ikan Bandeng (Chanos chanos Forsskal) di Balai Besar Perikanan Budidaya Air Payau (BBPBAP) Jepara
}

\author{
Andy Wicaksono ${ }^{a}$, Fuad Muhammad ${ }^{b}$, Jafron Wasiq Hidayat ${ }^{\mathrm{b}}$ dan Damang Suryanto $^{\mathrm{c}}$ \\ ${ }^{a}$ Departemen Biologi Fakultas Sains dan Matematika Universitas Diponegoro, Semarang \\ E-mail : andywicaksonoandy@gmail.com \\ ${ }^{\mathrm{b}}$ Departemen Biologi Fakultas Sains dan Matematika Universitas Diponegoro, Semarang \\ E-mail : fuad.muh@gmail.com \\ 'Balai Besar Perikanan Budidaya Air Payau (BBPBAP), Jepara \\ E-mail : bbpbapjpr@gmail.com
}

\begin{abstract}
Milkfish is one of the main commodities in the field of fishery and is known to be the most cultivated. One of the important's factors to the success of milkfish cultivation is feed availability, both quality and quantity. Feed quality is an important aspect that must be fulfilled because of its relation to nutrients required for the fish growth. Azolla pinnata has a good potential that can be used as an additional ingredient for the fish growth because of its protein-rich content. This study is aimed to examine the effect of Azolla pinnata powder feed on growth of milkfish (length and body weight). This research was conducted in May - July 2017 at Aquatic Animal Health Management Laboratory, Center of Brackish Water Aquaculture of Jepara. The research design used is a Complete Randomized Design (CRD), using five treatments with different concentrations of Azolla pinnata powder, i.e. 0\% as control, $10 \%, 20 \%, 30 \%$, and $40 \%$. Each treatments consist of three repeatitions. The parameters observed were milkfish growth (length and body weight) and dissolved oxygen (DO). Data were analyzed by Analysis of Variance (ANOVA) method. If the data showing significant differences it will be continued with Least Significance Different (LSD) test. The results showed that the administration of Azolla pinnata powder on the feed significantly influenced the growth (lenght and body weight) of milkfish. The most optimal and efficient feed composition for milkfish growth is done by feeding $40 \%$ of Azolla pinnata powder. The overall dissolved oxygen (DO) is still in suitable condition for the cultivation of milkfish.
\end{abstract}

Key Words : Azolla pinnata, dissolved oxygen, feed nutrition, milkfish

\begin{abstract}
Abstrak
Ikan bandeng merupakan salah satu komoditas andalan di bidang perikanan dan paling banyak dibudidayakan. Salah satu faktor penentu keberhasilan budidaya ikan bandeng adalah ketersediaan pakan, baik secara kualitas maupun kuantitas. Kualitas pakan merupakan aspek penting yang harus terpenuhi karena kaitannya dengan nutrisi yang dibutuhkan bagi pertumbuhan ikan. Tanaman Azolla pinnata memiliki potensi yang bagus untuk digunakan sebagai bahan tambahan penyusun ransum ikan karena kandungannya yang kaya akan protein. Penelitian ini bertujuan untuk mengkaji pengaruh pemberian tepung Azolla pinnata pada pakan terhadap pertumbuhan ikan bandeng (panjang dan bobot). Penelitian ini dilakukan pada bulan Mei - Juli 2017 di Laboratorium Manajemen Kesehatan Hewan Akuatik Balai Besar Perikanan Budidaya Air Payau Jepara. Rancangan penelitian yang digunakan adalah Rancangan Acak Lengkap (RAL), menggunakan lima perlakuan dengan berbagai kadar pemberian tepung Azolla pinnata yang berbeda, 0\% sebagai kontrol, 10\%, 20\%, 30\%, dan 40\%, masing-masing perlakuan terdiri dari tiga ulangan. Parameter yang diamati yaitu pertumbuhan ikan bandeng (panjang dan bobot) dan kandungan oksigen terlarut (DO). Data dianalisis dengan metode Analysis of Variance (ANOVA). Apabila menunjukkan perbedaan pertumbuhan secara signifikan akan dilanjutkan dengan uji Least Significance Different (LSD). Hasil penelitian menunjukkan bahwa pemberian tepung Azolla pinnata pada pakan memberikan pengaruh secara signifikan terhadap pertumbuhan ikan bandeng (panjang dan bobot). Komposisi pakan yang paling optimal dan efisien bagi pertumbuhan ikan bandeng adalah dengan pemberian tepung Azolla pinnata pada pakan sebesar $40 \%$. Secara keseluruhan, kandungan oksigen terlarut (DO) masih dalam kondisi yang layak untuk budidaya ikan bandeng.
\end{abstract}


Kata Kunci : Azolla pinnata, ikan bandeng, nutrisi pakan, oksigen terlarut

\section{PENDAHULUAN}

Indonesia merupakan negara kepulauan yang memiliki perairan yang sangat luas, oleh karenanya sektor perikanan merupakan salah satu sumber devisa negara yang sangat potensial. Salah satu budidaya ikan yang sangat potensial adalah budidaya ikan bandeng. Bandeng merupakan salah satu ikan yang memiliki potensi bagus jika dibudidayakan, karena ikan ini termasuk ikan yang tahan terhadap perubahan lingkungan sehingga tingkat produktivitasnya dapat dipertahankan. Keunggulan lain yang dimiliki adalah ikan ini tidak rentan terhadap serangan penyakit dan mudah dalam pemeliharaannya (Rachmansyah, 2004). Keberhasilan kegiatan budidaya ikan bandeng dipengaruhi oleh beberapa faktor, salah satunya adalah ketersediaan pakan, baik secara kualitas maupun kuantitas. Kualitas pakan yang meliputi kandungan nutrisi yang dibutuhkan bagi pertumbuhan ikan harus benar-benar dipenuhi, dan secara kuantitas (kecukupan jumlah pakan) pun harus dipenuhi, tidak kurang maupun tidak berlebih (Sukadi, 2003). Nutrien yang terkandung di dalam pakan berperan sebagai penentu pertumbuhan ikan. Nilai nutrisi pakan dapat dilihat dari komposisi gizinya, yang meliputi kandungan protein, lemak, serat kasar, vitamin, dan mineral. Salah satu kebutuhan nutrisi yang penting untuk ikan adalah protein, kekurangan protein dalam pakan dapat menyebabkan terhambatnya pertumbuhan ikan (Sukadi, 2003).

Di sekitar kita terdapat bahan baku yang kaya akan protein, yaitu tanaman Azolla pinnata. Tanaman ini memiliki potensi yang bagus untuk dimanfaatkan sebagai bahan tambahan pakan ikan karena kandungannya yang kaya protein. Azolla pinnata atau yang biasa disebut dengan mata lele dapat ditemukan hampir di semua persawahan Indonesia. Petani masih banyak yang menganggap bahwa tanaman ini berperan sebagai gulma. (Hidayat et al., 2011). Menurut Handajani (2007), Azolla pinnata merupakan tanaman air yang dapat ditemukan dari daratan rendah sampai ketinggian $2200 \mathrm{~m}$ di atas permukaan laut. Azolla banyak terdapat di perairan tenang seperti danau, kolam, rawa, dan persawahan. Namun tanaman ini tidak ditemukan di tambak maupun perairan payau. Azolla dianggap sebagai gulma air karena dalam waktu 3-4 hari dapat memperbanyak diri menjadi dua kali lipat dari berat segarnya, sehingga dapat menutupi permukaan perairan yang mengakibatkan berkurangnya aktifitas fotosintesis fitoplankton. Tanaman Azolla pinnata berpotensi sebagai pakan tambahan ikan karena tanaman ini memiliki kandungan protein yang cukup tinggi yaitu sebesar $25-30 \%$ yang sangat dibutuhkan bagi ikan, karena sumber utama pakan ikan adalah protein (Bittner, 1989).

Penelitian ini ditekankan pada keunggulan Azolla pinnata yang dapat dimanfaatkan sebagai pakan tambahan ikan karena kandungan proteinnya yang tinggi dengan komposisi asam amino yang lengkap (Winaya et al., 2010). Sudah ada beberapa penelitian mengenai pemanfaatkan Azolla sebagai pakan ikan, diantaranya adalah pemanfaatan Azolla sebagai pakan ikan nila (Sinaga, 2015) dan sebagai pakan ikan koi (Utami et al., 2013). Pemanfaatan tanaman Azolla pinnata sebagai pakan ikan bandeng masih terbatas informasinya. Ikan bandeng memiliki habitat di perairan payau, sementara Azolla memiliki habitat di perairan tawar, sehingga keduanya tidak dapat berinteraksi satu sama lain. Perlu dilakukan penelitian mengenai potensi tanaman Azolla sebagai bahan pakan tambahan ikan bandeng. Penggunaan Azolla diharapkan dapat menekan kebutuhan pelet sehingga dapat menekan biaya budidaya. Selain itu juga diharapkan dapat memperkaya nutrisi pakan bagi ikan sehingga dapat mempercepat pertumbuhan. Dengan kata lain manfaat yang dapat diperoleh yaitu dapat menekan biaya budidaya namun tidak menurunkan tingkat produktifitas ikan ketika panen.

\section{BAHAN DAN METODE}

\section{Waktu dan Tempat}

Penelitian dilakukan di Laboratorium MKHA (Manajemen Kesehatan Hewan Akuatik) Balai Besar Perikanan Budidaya Air Payau (BBPBAP) Jepara dan di Laboratorium Ilmu Nutrisi dan Pakan Universitas Diponegoro 
Semarang. Waktu penelitian dilaksanakan pada bulan Mei - Juli 2017.

\section{Alat dan Bahan}

Timbangan digital, mistar, 15 unit aerator, 15 unit wadah kontainer dengan ukuran volume 45 liter, ember, alat grading ikan, refraktometer, DO meter, blender, ayakan tepung, gelas ukur, serok ikan, selang sipon, pompa, oven, crucible porcelain, timbangan analitik ohaus, eksikator, gelas beaker, pinset, kompor listrik (hot plate), corong buchner, labu erlenmeyer, ekstraktor soxhlet, tanur listrik, labu penghisap (vacuump pump), labu destruksi, almari asam, dan pipet. Ikan bandeng umur 7 - 9 minggu dengan ukuran panjang $\pm 5 \mathrm{~cm}$ dan bobot \pm 2 gram berjumlah 300 ekor, air payau, tepung Azolla pinnata, progol, pelet T79-2 (ukuran $2.2-3.0 \mathrm{~mm}$ ) dengan kandungan protein $16-18 \%$, kertas saring Whatman, $\mathrm{NaOH}$, label, $\mathrm{H}_{2} \mathrm{SO}_{4}$, aquadest, nheksana, alkohol, katalisator campuran (cupri sulfat dan pottasium), asam sulfat pekat, $\mathrm{H} 3 \mathrm{BO} 3$ $4 \%$, indikator $\mathrm{MR}+\mathrm{BCG}, \mathrm{HCl}$, fenol $\left(\mathrm{C}_{6} \mathrm{H}_{5} \mathrm{OH}\right)$, natrium nitropusida $\left(\mathrm{C}_{5} \mathrm{FeN}_{6} \mathrm{Na}_{2} \mathrm{O}\right)$, larutan pengoksidasi (alkalin sitrat dan natrium hipoklorit), dan aluminium foil.

\section{Cara kerja}

Persiapan Ikan dan Media Uji

Wadah yang digunakan adalah kontainer dengan ukuran volume 45 liter berjumlah 15 unit. Sebelum digunakan, wadah dicuci bersih dan dikeringkan. Setelah itu air payau diisikan ke dalam kontainer dan diberi aerator sebagai penyuplai oksigen. Kemudian ikan dimasukkan ke dalam wadah, masing-masing wadah diisikan 20 ekor ikan dengan padat penebaran 2 liter air untuk 1 ekor ikan (Putri, 2016). Ikan diadaptasikan dan dipuasakan selama 24 jam, tujuannya untuk menghilangkan pengaruh sisa pakan yang lama dan menimbulkan rasa lapar, sehingga ikan dapat langsung memakan pelet yang sudah dimodifikasi dengan tepung Azolla. Sebelum dimulainya perlakuan, panjang dan bobot ikan diukur. Pengukuran panjang dan bobot ikan dilakukan setiap 10 hari selama 40 hari masa penelitian.

Air payau yang diinginkan adalah air yang memiliki kadar salinitas sebesar 15 ppt. Untuk menentukan kadar salinitas air yang diinginkan, digunakan rumus pengenceran menurut Budiyono (2013), yaitu sebagai berikut :

$$
\sin =\frac{\left(s 1 \times V_{1}\right)+\left(s 2 \times v_{2}\right)}{V 1-V^{2}}
$$

Sn adalah salinitas yang dikehendaki (ppt), S1 adalah salinitas air laut (ppt), S2 adalah salinitas air tawar (ppt).

\section{Perlakuan dan Komposisi Pakan}

Rancangan Percobaan yang dilakukan adalah rancangan acak lengkap (RAL), dengan 5 perlakuan berbeda dan 3 kali ulangan, yaitu P5A0 ( $100 \%$ pelet), P4A1 (90\% pelet $+10 \%$ Azolla), P3A2 (80\% pelet $+20 \%$ Azolla), P2A3 (70\% pelet $+30 \%$ Azolla), P1A4 (60\% pelet $+40 \%$ Azolla) . Dosis pakan harian sebesar 5\% dari total biomassa ikan, kemudian ditentukan penghitungan seberapa banyak gram pelet dan tepung Azolla yang diberikan perharinya untuk setiap perlakuan. Setelah kelima pakan perlakuan dibuat, dilanjutkan dengan uji proksimat untuk mengetahui kandungan nutrisi pada masing-masing pakan. Pemberian tepung Azolla pada pelet hanya sampai pada batas $40 \%$, karena perlu diperhatikan pula kesesuaian bentuk ukuran pelet dengan bukaan mulut ikan. Selain itu, dari hasil uji proksimat dengan pemberian tepung Azolla sebesar 40\% sudah menunjukkan adanya peningkatan kadar serat kasar sampai pada nilai yang mendekati ambang batas kelayakan, sehingga beresiko besar dapat mengganggu sistem pencernaan ikan.

\section{Pemberian Pakan dan Sistem Kontrol Air}

Pemberian pakan dilakukan sebanyak tiga kali dalam sehari, diberikan pada pagi hari pukul 07:00, siang hari pukul 13:00, dan sore hari pukul 17:00 WIB. Untuk mengatasi kekotoran media uji akibat penumpukan feses maupun sisa pakan yang terbuang, dilakukan sistem kontrol air dengan penggantian air. Penggantian air dilakukan setiap 10 hari dengan cara disifon setengah dari volume air, kemudian air baru ditambahkan ke dalam wadah. 


\section{Pembuatan Pakan Uji}

Azolla pinnata yang digunakan dalam bentuk tepung, tahap pembuatannya sebagai berikut :

Azolla pinnata diambil dan dicuci bersih dengan air mengalir untuk menghilangkan kotoran yang melekat pada Azolla.

Azolla kemudian ditiriskan dan dijemur di bawah sinar matahari hingga Azolla kering.

Azolla kering dihaluskan dengan cara diblender, hasil dari blenderan diayak dua kali hingga dihasilkan tepung yang halus.

Tepung Azolla sesuai dengan dosis pakan perlakuan dicampurkan dengan progol dalam wadah dan diaduk hingga merata. Dosis pemberian progol sebanyak 1 gram untuk masing-masing perlakuan.

Ditambahkan air sebanyak $125 \mathrm{ml}$ pada masingmasing adonan tadi, lalu diratakan dan dibiarkan selama 5 menit.

Selanjutnya pelet sesuai dengan dosis pakan perlakuan dituangkan ke dalam adonan tepung Azolla tadi dan diadukkan hingga Azolla lengket merata pada pelet.

Campuran pelet dengan tepung Azolla dikeringanginkan hingga benar-benar kering, kurang lebih selama $4-5$ jam.

\section{Pengukuran Panjang Ikan}

Pengukuran panjang ikan menggunakan rumusan pertumbuhan panjang menurut Effendie (1997), yaitu sebagai berikut :

$$
\Delta \mathrm{L}=\mathrm{Lt}-\mathrm{L} 0
$$

$\Delta \mathrm{L}$ adalah pertumbuhan panjang $(\mathrm{cm}), \mathrm{Lt}$ adalah panjang akhir ikan $(\mathrm{cm})$, L0 adalah panjang awal ikan $(\mathrm{cm})$.

\section{Pengukuran Bobot Ikan}

Pengukuran pertumbuhan bobot ikan menggunakan rumusan menurut Effendie (1997), yaitu sebagai berikut :

$$
\Delta W=W t-W_{0}
$$

$\Delta \mathrm{W}$ adalah pertumbuhan mutlak $(\mathrm{g})$, Wt adalah bobot akhir (g), Wo adalah bobot awal (g).

\section{Pengukuran Oksigen Terlarut (DO)}

Pengukuran oksigen terlarut dilakukan untuk mengetahui kondisi kualitas air media uji. DO merupakan salah satu faktor pembatas, sehingga keberadaannya dapat digunakan sebagai acuan apakah media pemeliharaan yang digunakan sudah layak untuk dilakukannya budidaya perikanan. Kandungan oksigen terlarut diukur dengan menggunakan alat DO meter, dilakukan pada hari ke $0,10,20,30$, dan 40 .

\section{Analisis Data}

Analisis data dilakukan untuk mengetahui pengaruh pemberian tepung Azolla pinnata pada pakan terhadap pertumbuhan ikan bandeng. Data pertumbuhan, baik itu panjang maupun bobot ikan yang telah diperoleh dianalisis dengan menggunakan metode Analysis of Variance. Apabila terdapat perbedaan pertumbuhan yang signifikan akibat pemberian tepung Azolla pada pakan, maka dilanjutkan dengan uji Least Significance Different. Untuk parameter oksigen terlarut dalam air (DO) dianalisis secara deskriptif.

\section{HASIL DAN PEMBAHASAN}

Pertumbuhan Panjang Ikan Bandeng

Pengukuran pertumbuhan panjang ikan bandeng (Chanos chanos) dilakukan di hari ke 0 , 10, 20, 30, dan 40. Hasil uji One Way Anova (ANOVA) didapatkan bahwa pada pengamatan hari ke 20 sudah mulai menunjukkan adanya perbedaan pertumbuhan panjang ikan bandeng secara signifikan akibat pemberian tepung Azolla pinnata pada pakan.

Keseluruhan data pengamatan (hari ke 0 40) diuji normalitasnya dengan menggunakan uji Shapiro-Wilk. Hasil uji tersebut menunjukkan bahwa data berdistribusi secara normal. Selanjutnya dari hasil uji Levene menunjukkan bahwa varians data yang dimiliki diasumsikan sama (homogen). Hasil uji One Way Anova menyatakan bahwa terdapat perbedaan pertumbuhan panjang yang signifikan akibat penambahan tepung Azolla pinnata pada pakan. Rata-rata pertumbuhan panjang ikan bandeng yang didapatkan bervariasi antara $1.05-1.29 \mathrm{~cm}$, dapat dilihat pada Tabel 1. 
Tabel 1. Pertumbuhan Panjang Ikan Bandeng

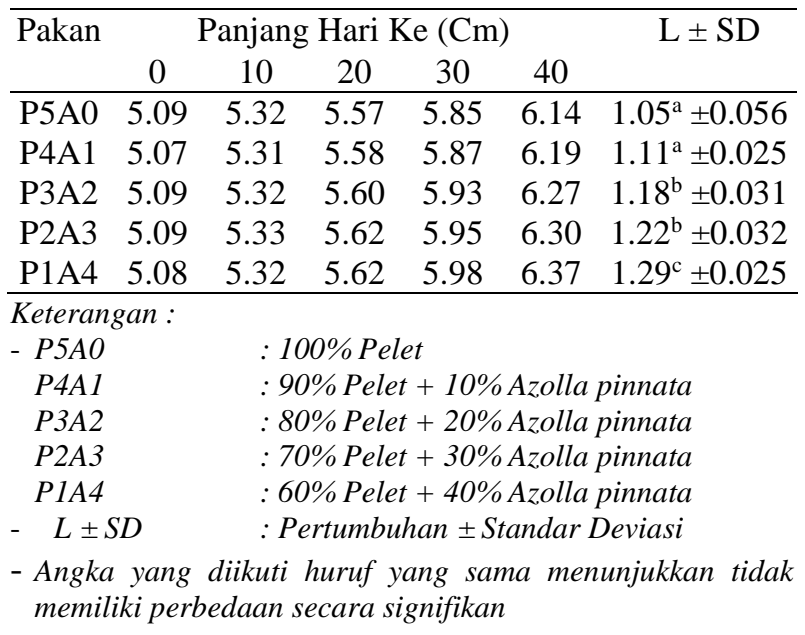

Hasil uji LSD menunjukkan bahwa pertumbuhan panjang ikan pada perlakuan P5A0 tidak berbeda secara signifikan dengan perlakuan P4A1, namun berbeda secara signifikan dengan perlakuan P3A2, P2A3, dan P1A4. Berdasarkan Tabel 1, terlihat bahwa pertumbuhan panjang ikan selama 40 hari dimulai dari ukuran panjang 5.07 $5.09 \mathrm{~cm}$ menjadi $6.14-6.37 \mathrm{~cm}$, terjadi penambahan panjang yang bervariasi antara $1.05-$ $1.29 \mathrm{~cm}$. Nilai pertumbuhan panjang ini kurang lebih hampir sama dengan hasil penelitian Putri (2016), dimana dengan pemberian pakan komersil selama 35 hari terjadi penambahan panjang ikan bandeng sebesar $1.30 \mathrm{~cm}$. Hasil perbandingan tersebut menunjukkan bahwa pakan komersil yang ditambahkan dengan tepung Azolla pinnata hingga pada taraf perbandingan sebesar 60\%: $40 \%$ dapat menghasilkan pertumbuhan panjang yang hampir sama dengan pemberian 100\% pakan komersil.

Pertumbuhan panjang ikan bandeng yang tertinggi terdapat pada perlakuan P1A4 dimana rata-rata pertumbuhan panjang ikan dan nilai SD sebesar $1.29 \mathrm{~cm} \pm 0.025$, berbeda secara signifikan dengan empat perlakuan lainnya (P5A0, P4A1, P3A2, dan P2A3). Dari hasil tersebut, dapat dinyatakan bahwa pemberian tepung Azolla pinnata pada pakan secara berturut-turut dari kadar $10 \%$ hingga $40 \%$ dapat semakin meningkatkan laju pertumbuhan panjang ikan bandeng. Grafik pertumbuhan panjang ikan bandeng (Chanos chanos) pada masing-masing perlakuan dapat dilihat pada Gambar 1.

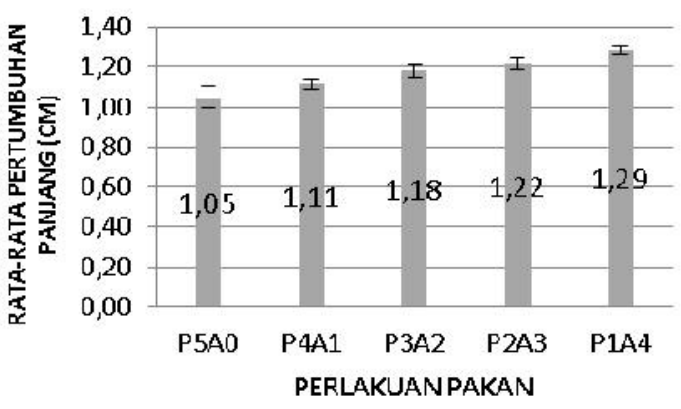

Gambar 1. Pertumbuhan Panjang Ikan

Terlihat pada Gambar 1, pertumbuhan panjang ikan bandeng pada perlakuan P1A4 merupakan pertumbuhan panjang yang paling tinggi jika dibandingkan dengan perlakuan lainnya. Hal ini disebabkan karena nilai nutrisi pakan, terutama nilai protein yang terkandung pada pakan P1A4 lebih baik jika dibandingkan dengan pakan perlakuan lainnya. Terbukti dari hasil uji proksimat yang tertera pada Tabel 2.

Tabel 2. Hasil Uji Proksimat Pakan Perlakuan

\begin{tabular}{cccccc}
\hline Pakan & $\begin{array}{c}\text { Protein } \\
(\%)\end{array}$ & $\begin{array}{c}\text { Lemak } \\
(\%)\end{array}$ & $\begin{array}{c}\text { Serat Kasar } \\
(\%)\end{array}$ & $\begin{array}{c}\text { Air } \\
(\%)\end{array}$ & $\begin{array}{c}\text { Abu } \\
(\%)\end{array}$ \\
\hline P5A0 & 18.07 & 4.97 & 10.92 & 9.73 & 7.23 \\
P4A1 & 20.45 & 4.00 & 12.81 & 9.69 & 9.48 \\
P3A2 & 22.64 & 3.80 & 15.14 & 9.47 & 11.07 \\
P2A3 & 24.66 & 3.53 & 17.34 & 9.81 & 13.65 \\
P1A4 & 26.65 & 2.69 & 18.49 & 9.85 & 15.12 \\
\hline
\end{tabular}

Keterangan :

P5AO : $100 \%$ Pelet

P4A1 : 90\% Pelet $+10 \%$ Azolla pinnata

P3A2 : $80 \%$ Pelet $+20 \%$ Azolla pinnata

P2A3 : $70 \%$ Pelet $+30 \%$ Azolla pinnata

P1A4 : $60 \%$ Pelet $+40 \%$ Azolla pinnata

Hasil uji proksimat menunjukkan bahwa pemberian tepung Azolla pinnata pada pakan dari kadar $10 \%$ hingga $40 \%$ dapat meningkatkan kandungan protein pakan. Kadar protein tertinggi terdapat pada pakan perlakuan P1A4 (26.65\%), diikuti dengan pakan perlakuan P2A3 (24.66\%), P3A2 (22.64\%), P4A1 (20.45\%), dan P5A0 $(18.07 \%)$. Peningkatan kandungan protein dari $18.07 \%$ menjadi $26.65 \%$ terbukti dapat memenuhi kriteria pakan yang baik. Menurut Noegroho (2000), kisaran kebutuhan protein dalam pakan untuk ikan daerah tropis seperti bandeng adalah 
pakan dengan kadar protein antara $20-60 \%$. Protein memegang peranan penting dalam penyusunan jaringan dan organ tubuh ikan. Protein yang rendah akan mengakibatkan pertumbuhan ikan menjadi lambat dan tidak optimal. Disisi lain, Buwono (2000) mengungkapkan bahwa ikan tidak mempunyai kebutuhan protein yang mutlak, namun untuk menunjang pertumbuhannya, ikan membutuhkan suatu campuran yang seimbang antara asam amino esensial dan non-esensial.

Selain terjadi peningkatan kandungan protein akibat pemberian Azolla, terjadi pula peningkatan kadar serat kasar. Kandungan serat kasar pada pakan semakin meningkat seiring dengan banyaknya tepung Azolla yang diberikan. Secara keseluruhan $(0-40 \%$ Azolla pinnata $)$ terjadi peningkatan kadar serat kasar dari $10.92 \%$ menjadi $18.49 \%$. Menurut Afrianto \& Liviawaty (2005), kandungan serat kasar dalam pakan dianjurkan tidak lebih dari $21 \%$, karena bila terlalu tinggi justru dapat mengganggu daya cerna dan daya serap dalam pencernaan ikan. Oleh karenanya dapat dinyatakan bahwa peningkatan kandungan serat kasar dalam pakan masih dalam kategori yang layak untuk diberikan.

Kandungan nutrisi pakan masing-masing perlakuan pun dicerminkan dengan pertumbuhan panjang ikan bandeng (Chanos chanos). Dari semua komposisi tepung Azolla pinnata yang diberikan, komposisi yang paling optimal bagi pertumbuhan panjang ikan bandeng ada pada perlakuan P1A4 dengan pemberian tepung Azolla pinnata pada pakan sebanyak $40 \%$.

\section{Pertumbuhan Bobot Ikan Bandeng}

Pengukuran pertumbuhan bobot ikan bandeng juga dilakukan di hari ke 0, 10, 20, 30, dan 40. Hasil uji One Way Anova didapatkan bahwa pada pengamatan hari ke 20 sudah mulai menunjukkan adanya perbedaan pertumbuhan bobot ikan secara signifikan akibat pemberian tepung Azolla pinnata pada pakan.

Keseluruhan data pengamatan (hari ke 0 40) yang telah diperoleh, diuji normalitas datanya dengan menggunakan uji Shapiro-Wilk. Hasil uji tersebut menunjukkan bahwa data yang diperoleh berdistribusi secara normal. Selanjutnya dari hasil uji Levene menunjukkan bahwa varians data yang dimiliki diasumsikan sama (homogen). Hasil uji
One Way Anova menyatakan bahwa terdapat perbedaan pertumbuhan bobot yang signifikan akibat penambahan tepung Azolla pinnata pada pakan. Rata-rata pertumbuhan bobot ikan bandeng yang didapatkan bervariasi antara $2.00-2.27$ gram, dapat dilihat pada Tabel 3.

Tabel 3. Pertumbuhan Bobot Ikan Bandeng

\begin{tabular}{|c|c|c|c|c|c|c|}
\hline \multirow[t]{2}{*}{ Pakan } & \multicolumn{5}{|c|}{ Bobot Hari Ke (Gram) } & \multirow[t]{2}{*}{$\Delta \mathrm{W} \pm \mathrm{SD}$} \\
\hline & 0 & 10 & 20 & 30 & 0 & \\
\hline PJAU & .08 & 247 & .97 & 3.5 & 0 & \\
\hline P4A1 & 2 & & 8 & 3 & & \\
\hline P3A2 & & & 2. & 3. & & 0.03 \\
\hline $\mathrm{P} 2 \mathrm{~A} 3$ & 8 & 2 & 3.03 & 3.62 & 7 & \pm 0.02 \\
\hline $\mathrm{P} 1 \mathrm{~A} 4$ & 2.08 & 2.49 & 3.04 & 3.67 & 4.35 & $2.27^{\mathrm{e}} \pm 0.03$ \\
\hline
\end{tabular}

Keterangan :

- P5AO

$: 100 \%$ Pelet

P4A1

: $90 \%$ Pelet $+10 \%$ Azolla pinnata

$P 3 A 2$

$: 80 \%$ Pelet $+20 \%$ Azolla pinnata

$P 2 A 3$

: $70 \%$ Pelet $+30 \%$ Azolla pinnata

P1A4 : $60 \%$ Pelet $+40 \%$ Azolla pinnata

- $\triangle W \pm S D \quad:$ Pertumbuhan \pm Standar Deviasi

- Notasi huruf yang berbeda menyatakan terdapat perbedaan secara signifikan

Hasil uji LSD menunjukkan bahwa pertumbuhan bobot ikan bandeng pada tiap taraf perlakuan saling berbeda secara signifikan. Itu artinya pada perlakuan P5A0, P4A1, P3A2, P2A3, dan P1A4 memiliki pertumbuhan bobot yang berbeda nyata satu sama lain. Terlihat pada Tabel 3 , pertumbuhan bobot ikan selama 40 hari masa pemeliharaan dimulai dari bobot $2.08-2.09$ gram menjadi 4.08 - 4.35 gram, terjadi penambahan bobot yang bervariasi antara $2.00-2.27$ gram. Nilai pertumbuhan tersebut kurang lebih hampir sama dengan hasil penelitian Putri (2016) dan Jatmiko et al. (2016). Dimana dalam penelitian Putri (2016), dalam kurun waktu 35 hari dengan pemberian pakan komersil yang ditambahkan $2 \%$ molase menghasilkan pertumbuhan bobot sebesar 1.53 gram. Sedangkan dalam penelitian Jatmiko et al. (2016), dalam kurun waktu 34 hari dengan pemberian $100 \%$ pakan komersil (kadar protein $36 \%$ ) dan 2\% klekap kering, terjadi penambahan bobot sebesar 2.12 gram. Dari perbandingan tersebut, diyakini pakan komersil yang ditambahkan dengan tepung Azolla pinnata hingga pada taraf perbandingan sebesar 60\%: $40 \%$ dapat 
menghasilkan pertumbuhan bobot yang hampir sama dengan pemberian $100 \%$ pakan komersil.

Pertumbuhan bobot yang tertinggi terdapat pada perlakuan P1A4, dimana rata-rata pertumbuhan bobot ikan dan nilai SD sebesar 2.27 gram \pm 0.031 , berbeda secara signifikan dengan empat perlakuan lainnya (P2A3, P3A2, P4A1, P5A0). Dari hasil tersebut, dapat dinyatakan bahwa pemberian tepung Azolla pinnata pada pakan secara berturut-turut dari kadar 10\% hingga $40 \%$ dapat semakin meningkatkan laju pertumbuhan bobot ikan bandeng. Grafik pertumbuhan bobot ikan bandeng masing-masing perlakuan tertera pada Gambar 2.

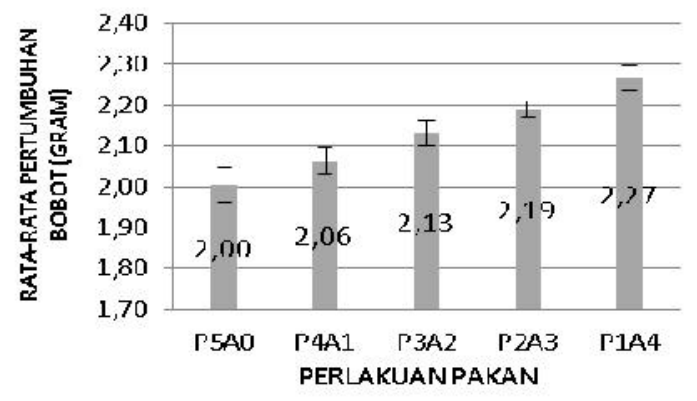

Gambar 2. Pertumbuhan Bobot Ikan

Pertumbuhan bobot ikan bandeng (Chanos chanos) pada perlakuan P1A4 merupakan pertumbuhan bobot yang paling tinggi jika dibandingkan dengan perlakuan lainnya. Hal tersebut terjadi karena diyakini pakan dengan penambahan tepung Azolla berturut-turut dari taraf $10 \%-40 \%$ dapat memperkaya nutrisi pada pelet, utamanya kandungan protein. Sebagaimana yang telah diuraikan pada Tabel 2, kandungan protein dalam pakan semakin meningkat seiring dengan banyaknya kadar tepung Azolla yang diberikan. Menurut Putri (2011), kebutuhan protein merupakan aspek penting dalam nutrisi ikan karena protein merupakan salah satu nutrien yang diperlukan oleh ikan untuk pertumbuhan. Protein yang diserap oleh ikan akan dimanfaatkan untuk membangun atau memperbaiki sel-sel tubuh yang rusak, serta dimanfaatkan tubuh ikan bagi metabolisme sehari-hari. Cepat tidaknya pertumbuhan ikan ditentukan oleh banyaknya protein yang dapat diserap dan dimanfaatkan oleh tubuh sebagai zat pembangun.
Penggunaan tepung Azolla sebagai sumber protein tambahan terbukti dapat memperkaya kandungan nutrisi dalam pakan. Lovell (1988) pun berpendapat bahwa penggunaan dua atau lebih sumber protein dalam ransum akan lebih baik dari pada satu sumber. Dalam hal ini sumber protein tambahan yang digunakan untuk pakan ikan berasal dari Azolla pinnata. Sementara sumber protein utama berasal dari pelet (pakan komersil) itu sendiri. Tingkat pertumbuhan ikan bandeng yang semakin tinggi seiring dengan banyaknya tepung Azolla pinnata yang diberikan pada pakan diyakini juga karena ikan bandeng lebih meyukai pakan yang telah diberi tepung Azolla. Hal ini didasari dari fakta bahwa ikan bandeng merupakan jenis ikan herbivora. Oleh karenanya, dimungkinkan ikan bandeng lebih menyukai pakan yang telah diberi tepung Azolla. Hal ini sesuai dengan pendapat Putri (2011) yang menyatakan bahwa ketika fase larva, ikan bandeng tergolong karnivora. Kemudian pada ukuran fry atau juvenil termasuk ke dalam golongan herbivora. Pada fase ini ikan bandeng sudah bisa memakan pakan buatan berupa pelet.

Selain terjadi peningkatan kandungan protein, penambahan tepung Azolla juga meningkatkan kandungan serat kasar. Terjadi peningkatan kadar serat kasar dari $10.92 \%$ $18.49 \%$. Itu artinya pemberian tepung Azolla berturut-turut dari kadar $10 \%$ hingga $40 \%$ dapat semakin memperkaya kandungan serat kasar dalam pakan. Dengan demikian, terjadi peningkatan kandungan karbohidrat dalam pakan seiring dengan banyaknya kadar tepung Azolla pinnata yang diberikan. Sesuai pendapat Mahyudin (2008), karbohidrat terdiri dari serat kasar dan bahan ekstrak tanpa nitrogen (BETN). Kebutuhan karbohidrat pada ikan dipengaruhi oleh kebiasaan makannya atau jenis ikan itu sendiri. Ikan herbivora membutuhkan karbohidrat yang lebih lebih besar jika dibandingkan dengan ikan karnivora. Oleh karena ikan bandeng merupakan ikan jenis herbivora, yang mana membutuhkan asupan karbohidrat yang cukup tinggi, pertumbuhan bobot pada perlakuan P1A4 lebih baik jika dibandingkan dengan perlakuan lainnya (P5A0, P4A1, P3A2, dan P2A3). Masyamsir (2001) berpendapat bahwa ikan herbivora membutuhkan karbohidrat sampai $50 \%$ dalam 
pakannya. Ikan herbivora mampu menghasilkan enzim amilase di sepanjang saluran pencernaannya, sehingga ikan herbivora lebih mampu dan lebih efisien dalam memanfaatkan karbohidrat. Hal tersebut sejalan dengan pendapat Mahyudin (2008) yang menyatakan bahwa kebutuhan karbohidrat pakan untuk ikan bandeng berkisar antara $30-45 \%$.

\section{Kandungan Oksigen Terlarut (DO)}

Di dalam kegiatan budidaya ikan bandeng (Chanos chanos) perlu diperhatikan juga fakor lingkungan media budidayanya, seperti suhu, $\mathrm{pH}$, DO, dan kandungan amonia air. Kualitas air media budidaya dapat secara langsung mempengaruhi kelangsungan hidup dan pertumbuhan ikan bandeng. Menurut Fujaya (2000), faktor lingkungan seperti $\mathrm{pH}$, suhu, dan DO dapat saling mempengaruhi, baik dalam arti saling menunjang maupun saling menghalangi di dalam pertumbuhan ikan. Parameter kualitas air yang diukur dalam penelitian ini adalah kandungan oksigen terlarut (DO). Hasil pengamatan kandungan oksigen terlarut (DO) dapat dilihat pada Tabel 4.

Tabel 4. Kandungan Oksigen Terlarut (DO)

\begin{tabular}{cc}
\hline Perlakuan & DO $(\mathrm{mg} / \mathrm{l})$ \\
\hline P5A0 & 4.63 \\
P4A1 & 4.49 \\
P3A2 & 4.51 \\
P2A3 & 4.67 \\
P1A4 & 4.60 \\
\hline Baku Mutu & $3-6$ \\
\hline
\end{tabular}

Keterangan :

P5AO : $100 \%$ Pelet

P4A1 : $90 \%$ Pelet $+10 \%$ Azolla pinnata

P3A2 : $80 \%$ Pelet $+20 \%$ Azolla pinnata

P2A3 : $70 \%$ Pelet $+30 \%$ Azolla pinnata

P1A4 : $60 \%$ Pelet $+40 \%$ Azolla pinnata

Berdasarkan Tabel 4, secara keseluruhan kandungan oksigen terlarut dalam air (DO) masih berada dalam kategori yang layak bagi ikan bandeng untuk tumbuh dan berkembang. Kandungan oksigen terlarut (DO) secara keseluruhan tercatat dalam kisaran 4.49 - 4.67 mg/l. Menurut Sabriah \& Sunarto (2009), kisaran DO yang baik untuk pertumbuhan ikan bandeng antara $3-6 \mathrm{mg} / \mathrm{l}$. Sedangkan berdasarkan standar baku mutu dalam Peraturan Pemerintah No. 20 tahun 1990, konsentrasi kandungan oksigen terlarut (DO) dianjurkan sebesar $\geq 3 \mathrm{mg} / \mathrm{l}$ (Libriyanto, 2008). Oksigen merupakan salah satu faktor pembatas, sehingga bila ketersediaannya tidak mencukupi kebutuhan biota budidaya budidaya, maka segala aktivitas biota akan terhambat. Ikan membutuhkan oksigen guna pernapasan dan pembakaran bahan bakarnya (makanan) untuk menghasilkan aktivitas seperti berenang, pertumbuhan, dan reproduksi. Oleh karena itu, kekurangan oksigen dalam air (DO) dapat mengganggu kehidupan ikan, termasuk kepesatan pertumbuhannya, dan bahkan dapat mengakibatkan kematian (Kordi \& Tancung, 2007).

\section{KESIMPULAN}

Kesimpulan

Berdasarkan hasil yang diperoleh, dapat ditarik kesimpulan yaitu pemberian tepung Azolla pinnata pada pelet berpengaruh baik terhadap pertumbuhan ikan bandeng, baik itu pertumbuhan panjang maupun pertumbuhan bobot. Pertumbuhan yang paling optimal dan efisien terdapat pada perlakuan P1A4 dengan pemberian tepung Azolla pinnata sebesar 40\%. Kandungan oksigen terlarut secara kesuluruhan masih dalam kondisi yang ideal bagi budidaya ikan bandeng.

\section{Saran}

Tingginya serat kasar pada pakan akibat pemberian tepung Azolla beresiko tinggi mengganggu sistem pencernaan ikan, oleh karenanya diperlukan penelitian lebih lanjut untuk mengatasi kenaikan tersebut. Apabila kenaikan kadar serat kasar yang melebihi batas dapat diatasi, maka harapannya Azolla pinnata dapat dipergunakan sepenuhnya sebagai bahan pokok pembuatan pakan ikan.

\section{UCAPAN TERIMA KASIH}

Penulis ucapkan terima kasih kepada Bapak Sugeng Raharjo, A. Pi selaku Kepala Balai Besar Perikanan Budidaya Air Payau (BBPBAP) Jepara dan Departemen Biologi Fakultas Sains dan Matematika Universitas Diponegoro Semarang 
yang telah menyediakan fasilitas dan memberikan izin untuk kegiatan penelitian.

\section{DAFTAR PUSTAKA}

Afrianto, E. \& E. Liviawaty. 2005. Pakan Ikan dan Perkembangannya. Kanisius. Yogyakarta.

Bittner, A. 1989. Budidaya Air. Yayasan Bogor Indonesia. Jakarta.

Budiyono, R. 2013. Pengaruh Salinitas Terhadap Pertumbuhan Ikan Sidat Fase Glass Eel Sebagai Alternatif Teknologi Budidaya Ikan Sidat (Anguilla bicolor bicolor). Skripsi. Jurusan Biologi Fakultas Matematika dan Ilmu Pengetahuan Alam Universitas Sebelas Maret, Surakarta.

Buwono, I.D. 2000. Kebutuhan Asam Amino Esensial Dalam Ransum Ikan. Kanisius. Yogyakarta.

Effendie, M.I. 1997. Biologi Perikanan. Yayasan Pustaka Nusantara. Jakarta.

Fujaya, Y. 2000. Fisiologi Ikan Dasar. Pengembangan Teknik Perikanan. Rineka Cipta. Jakarta.

Handajani, H. 2007. Peningkatan Nilai Nutrisi Tepung Azolla Melalui Fermentasi. Naskah Publikasi. Fakultas Peternakan Perikanan Universitas Muhammadiyah Malang. Malang.

Hidayat, C., A. Fanindi., S. Sopiyana., \& Komarudin. 2011. Peluang Pemanfaatan Tepung Azolla Sebagai Bahan Pakan Sumber Protein untuk Ternak Ayam. Seminar Nasional Teknologi Peternakan dan Veteriner. Bogor.

Jatmiko, F.D., A. Deamanti, Zulfiani, A.E. Setiawan, F.I. Haq, A.H. Laeli, D.P. Akmalia, E.P. Kusuma, \& C.P. Sina. 2016. Pembesaran Bandeng (Chanos chanos) untuk Umpan Pancing Ikan Laut Dengan Sistem Resirkulasi. Hasil Praktik Keahlian. Jur. Teknologi Akuakultur Sekolah Tinggi Perikanan, Jakarta.

Kordi, G. \& A.B. Tancung. 2007. Pengelolaan Kualitas Air Dalam Budidaya Perairan. Rineka Cipta. Jakarta.

Libriyanto, O. 2008. Pengaruh Penggunaan Lahan Tambak Terhadap Kualitas Air Saluran Irigasi Tambak di Muara Daerah Aliran Ci
Manceuri (Kabupaten Tangerang). FMIPA UI. Depok.

Lovell, T. 1988. Fish Nutrition. Academic Press. London and New York.

Mahyudin, K. 2008. Panduan Lengkap Agribisnis Ikan Lele. Penebar Swadaya. Jakarta.

Masyamsir. 2001. Membuat Pakan Ikan Buatan. Departemen Pendidikan Nasional. Jakarta.

Noegroho, F.P. 2000. Pengaruh Penggunaan Tepung Terigu, Tepung Singkong, dan Campuran Keduanya Dalam Pakan Terhadap Pertumbuhan Ikan Patin (Pangasius sp.). Skripsi. IPB, Bogor.

Putri, D.S. 2011. Pengaruh Tingkat Substitusi Tepung Ikan Dengan Tepung Maggot Terhadap Komposisi Kimia Pakan dan Tubuh Ikan Bandeng (Chanos chanos Forsskal). Skripsi. Program Studi Budidaya Perairan Jurusan Perikanan Fakultas Ilmu Kelautan dan Perikanan Universitas Hasanuddin, Makassar.

Putri, M.H. 2016. Pengaruh Beberapa Konsentrasi Molase Terhadap Pertumbuhan Ikan Bandeng (Chanos chanos Forsskal) dan Kualitas Media Air. Skripsi. Jurusan Biologi Fakultas Sains dan Matematika Universitas Diponegoro, Semarang.

Rachmansyah. 2004. Analisis Daya Dukung Lingkungan Perairan Teluk Awarange Kabupaten Baru, Sulawesi Selatan Bagi Pengembangan Budidaya Bandeng Dalam Keramba Jaring Apung. IPB. Bogor.

Sabriah \& Sunarto. 2009. Pemberian Pakan Buatan Dengan Dosis Yang Berbeda Terhadap Pertumbuhan dan Konsumsi Pakan Benih Ikan Semah Dalam Upaya Domestikasi. Jurnal Akuakultur Indonesia 8 (1): 67 - 76.

Sinaga, D. 2015. Tingkat Penggunaan Azolla pinnata pada Pakan Terhadap Pertumbuhan Ikan Nila (Oreochromis niloticus). Skripsi. Fakultas Pertanian Universitas Sumatera Utara. Medan, Medan.

Sukadi, M.F. 2003. Strategi dan Kebijakan Pengembangan Pakan Dalam Budidaya Perikanan. Prosiding Semi-Loka Aplikasi Teknologi Pakan dan Peranannya Bagi Perkembangan Usaha Perikanan Budidaya. Pusat Riset Perikanan Budidaya. Badan 
Riset Kelautan dan Perikanan. Hlm.: 11 21.

Utami, D.A.T., A. Yuniarti, \& P. Sinung. 2013. Variasi Kombinasi Tepung Labu Kuning (Cucurbita moschata D.) dan Tepung Azolla (Azolla pinnata R.br.) pada Kecerahan Warna Ikan Koi (Cyprinus carpio L.). Universitas Atma Jaya. Yogyakarta.
Winaya, A., Maftuchah, \& A. Zainudin. 2010. Tanaman Air Azolla sp. Sebagai Tambahan Pakan dan Pengaruhnya Terhadap Tampilan Produksi Ayam Broiler. Strain Hubbard. Jurnal Sain Peternakan Indonesia V (1).hhBoyce, P.C., S. Y. Wong, A. P. J. Ting, S. E. Low, K. K. Ng, I. H. Ooi. 2010. The Araceae of Borneo- The genera. Journal ofAroideana Vol.33. 